\title{
Spa, Spa Tourism and Wellness Tourism in the Czech Republic
}

\section{Jiří Vystoupil / Martin Šauer / Markéta Bobková}

e-mail: vyst@econ.muni.cz, sauer@econ.muni.cz,mar.novotna@econ.muni.cz

Institute of Tourism, Department of Regional Economics and Administration, Faculty of Economics and Administration, Masaryk University, Brno, Czech Republic

Vystouil, J., Šauer, M., \& Bobková, M. (2017). Spa, Spa Tourism and Wellness Tourism in the Czech Republic. Czech Journal of Tourism, 6(1), 5-26. DOI: 10.1515/cjot-2017-0001.

\begin{abstract}
The aim of this paper is to compare and assess the position of the spa and wellness sector in the structure of tourism in the Czech Republic. In this context, the article deals with the brief history of the Czech spa tourism and the development of spa tourism in the spa resorts, including the focus of specialized literature review. The methodological part consists of an explanation of the existing statistical information about the spa sector. The main part of the paper deals with the geographic analysis of current spa centres (the capacity of spa and total collective accommodation facilities, the number of spa patients and guests, guest attendance and their geographical structure). The assessment also includes the determination of the importance of the spa for overall spa tourism. Furthermore, the paper also deals with the development and localization of the selected forms of wellness tourism. As a pilot example, aquaparks built especially in the last 20 years in the Czech Republic were chosen.
\end{abstract}

\section{Key words}

spa, spa tourism, wellness tourism, regional and resort analysis

JEL classification: I13, L83, Q26 


\section{Introduction}

In the middle of the 19th century, primarily the medical opinions prevailed in the Czech lands that tourism was not part of the spas. The early 20th century completely changed this point of view. The reasons were simple. The high social and cultural attractiveness of the spas and their economic efficiency brought not only patients to the spas, but also a higher social clientele for various spas stays (including relaxing, cultural and sports activities). Until the year 1948, the development of the former spa was associated with the commercial prosperity of joint stock companies, insurance institutions and private entrepreneurs who owned the spa facilities. The reputation of the spa was also reflected in the composition of the spa guests - Vystoupil (1977) presented, that by the end of the 20th century the share of foreign guests was almost 50\%. In the West Bohemian Triangle, it was even $70-80 \%$ of the total attendance.

The first professional studies on spa, respectively on spa tourism, emerged with the existence of relevant information and statistics on spa care (e.g., diagnosis, therapeutic effects) and on a number of guests. This information was related to the balneological importance of spa care as a whole, and also to the economic benefit from the spa attendance. Selected information about the most important spas was available from the end of the 19th century, but detailed comparative statistics for most of the spa centres were available until the end of the 1930s. Černý (1945) and Charvát (1948) was among the founders of pre-war tourism studies.

In the post-war period, research progressively expanded to a wide range of spa themes, which can be, particularly in recent years, summed up for the purposes of this article as follows:

- Classical and specific medical and balneological research (e.g., studies of civilization diseases and their diagnosis, possibilities of their treatment with natural resources and curative thermal springs, therapeutic specifics of individual spas - Kajlík, 2007; Institute of Health Information and Statistics of the Czech Republic, 2009, 2010, 2011, 2012, 2013, 2014, 2015, 2016; Špišák et al., 2010).

- Building national and regional statistics of spa care, spa sites (Institute of Health Information and Statistics of the Czech Republic, 2009, 2010, 2011, 2012, 2013, 2014, 2015, 2016; Czech Statistical Office, 2017).

- National and regional analyses and evaluation of the offer, the attendance of spa resorts, assessment of the importance of spas for tourism. In this context, there are many studies on the number of spa resorts and their capacities, the diagnoses and numbers of treated patients, and the numbers and geographic structure of the spa guests arriving for relaxation, recreation, and entertainment (e.g., Vystoupil, 1977; Fialová, 2004; Attl, 2006b; Migala \& Szczyrba, 2006; Kajlík, 2007; Sudíková, 2009; Kunc, 2011; Vaníček \& Vavrečková, 2013a; Vavrečková, 2015; Czech Statistical Office, 2017).

- Analysis of economic benefits of spa and spa tourism (e.g. Černý, 1969; Vavrečková \& Vanicek, 2014).

- Research of the demand for spa and spa tourism - marketing research of spa products, profile, and satisfaction of spa visitors (e.g., Seifertová, 2003; Kostková et al., 
2009; Vaníček \& Vavrečková, 2013b; Jakubíková \& Vildová, 2014; Vildová, Martinčík, Tlučhoř \& Jakubíková, 2015).

- Summative encyclopaedic and cartographic studies of spa issues (Burachovič \& Wieser, 2001; Houdek, 2003; Smolová, 2004; Vystoupil et al., 2006).

- Spa protection - legislative issues, protection of spas before urbanization, issues of optimum spa size (Chovanec, 1966; Trachta, 1973; Benda, 1979).

- Health-oriented tourism and its forms of wellness (Attl, 2006a; Poděbradský, 2008; Kubová, 2012; Benešová \& Kruisová, 2013, 2015; Schwartzhoffová, 2016).

\section{Brief history and basic concepts}

The history and tradition of the Czech spa is an inseparable part of the European cultural heritage. The first written reports date back to the 15 th and 16 th centuries. The more significant development of spa occurred at the turn of the 17th and 18th centuries when Teplice in Bohemia became the first spa of European importance. The period of the greatest spawning in the Czech Republic was the turn of the 19th and 20th centuries. At that time, the largest spa centres became real social and cultural centres where important persons of cultural, scientific and political life met (Fialová, 2004). The period until 1938 is not only in the Czech Republic but also throughout Europe called the "Golden Age of Spa". The planned completion of the spa complexes and the establishment of modern treatment facilities were implemented (Kunc, 2011, p. 120). The Czech spa has begun to gain renown in the world based on the effectiveness of the healing procedures and the quality of the spa physicians. It has thus become comparable to developed Western European countries.

Spas have always been attractive tourism centres with significant economic benefits in the Czech Republic. As Vystoupil (1977) noted, in 1927, 400 thousand guests (of which $46 \%$ came from abroad) came to the 39 Czechoslovak spa centres existent at that time; it is almost $20 \%$ of all tourists out of the total number of visitors of Czechoslovakia (of which 76\% were in Czech and Moravian Spa). The economic benefit was mainly due to the long-term stays of spa guests who spent more than 6 million days there (with an average stay of about 15 days). The international attractiveness of the Czech foremost spas in the pre-war period is documented by the shares of foreign guests. In 1930, the share of foreign guests in Karlovy Vary was 73\%, in Mariánské Lázně 88\%, in Jáchymov 48\%, and in Luhačovice $20 \%$ out of the total number of their accommodated visitors.

The period after the Second World War up to 1989 can be characterized by a certain decline in the importance of the Czech spa. The causes can be found mainly in the postwar expulsion of the German population from the Sudeten area and the nationalization of natural healing springs and the spa, associated with the cessation of non-healing activities (Kunc, 2007, p. 1). One of the negative trends was also the decline in foreign visitors in most of the Czech spa resorts. The overall level of health care remained relatively high in the Czech Republic, but the accompanying services could not be compared to developed Western Europe. 
Table 1 Historical development of the most important spas in the Czech Republic

\begin{tabular}{|l|c|c|l|c|c|}
\hline \multirow{2}{*}{ spa resort } & \multicolumn{2}{|c|}{$\begin{array}{c}\text { number of guests } \\
\text { in ths. }\end{array}$} & \multirow{2}{*}{ spa resort } & \multicolumn{2}{|c|}{$\begin{array}{c}\text { number of guests } \\
\text { in ths. }\end{array}$} \\
\cline { 2 - 4 } \cline { 5 - 6 } & $\mathbf{1 9 2 7}$ & $\mathbf{2 0 1 5}$ & & $\mathbf{1 9 2 7}$ & $\mathbf{2 0 1 5}$ \\
\hline Karlovy Vary & 111 & 267 & Jáchymov & 9 & 36 \\
\hline Mariánské lázně & 60 & 233 & Jeseník & 8 & 44 \\
\hline Teplice & 60 & 44 & Janské Lázně & 5 & 55 \\
\hline Františkovy Lázně & 46 & 106 & Lázně Libverda & 1 & 11 \\
\hline Luhačovice & 26 & 107 & Konstantinovy Lázně & 1 & 11 \\
\hline Špindlerův Mlýn & 22 & - & Lázně Kynžvart & 1 & 6 \\
\hline Poděbrady & 22 & 57 & & & \\
\hline
\end{tabular}

Source: State Statistical Office (1928, pp. 346-349), Czech Statistical Office (2017)

The privatization and transformation of the spa sector after 1989 brought several fundamental changes. The transformation in 1992 contributed to the formation of more than 50 new spa organizations from originally 12 state spa organizations (Smolová \& Szczyrba, 2005). In spite of some negative aspects (e.g., the temporary extinction of some smaller spas), there was a significant increase in the standard range of treatment stays for new forms of relaxation and regeneration stays (health tourism). Spa tourism became a popular way of spending leisure time.

There are relatively many natural treatment resources (especially thermal springs) in the Czech territory, and new spa resorts are gradually established in their vicinity. As a result, the trend of reduction of spas turned the opposite way. The new spas are created mainly in traditional places where the spas existed in the past and which have good conditions for the development of spa activities (e.g. Skalka, Lednice, Klášterec nad Ohří). But there are also completely new places where interesting projects of new spa or spa-wellness centres are carried out (Attl, 2006b).

There are currently 36 spa resorts in the Czech Republic that are grouped under the headquarters of the Association of Spa Resorts of the Czech Republic. The spa resorts use natural resources, which are divided into the categories of thermal, muddy, radon, mud, climatic and mineral baths. The visitor can choose not only the type of bath but also the way of accommodation or meals, the length of stay, relaxation and wellness procedures. Guests can also take part in many cultural activities or take excursions into the surroundings of the spa. The spa towns have not only the unmistakable charm of architecture, but they also allow the visitor to enjoy the comfort combined with ancient healing procedures. The modern trend includes the fitness, preventive health and the so-called wellness stays in the spa. Thanks to the traditions and reputation of the Czech spa resorts and clientele from upper middle classes with above-average expenditures, spa is one of the key forms of active tourism. In addition to this, the spa and spa services contribute to the reduction of the seasonality of individual tourist sites, which is a positive 
fact for the Czech Republic as a typical seasonal destination. Hence, according to the distribution of participation during the year, the spa is sometimes referred to as a yearround kind of tourism.

What is actually a spa or a spa resort? According to the Explanatory Dictionary of Tourism, the spa consists of a complex „of accommodation, catering, rehabilitation, sports and medical equipment, using natural and medicinal resources (e.g., mineral and thermal springs, peloids, humidity, mud, hot gases, climatic conditions, sea, and caves) and healing procedures to achieve a healing effect on clients. According to the natural resources, the thermal, climatic and mud baths are often divided“ (Zelenka \& Pásková, 2012, p. 305).

In the Czech Republic, the basic functional and spatial unit of the spa organization is the so-called spa resort. In the sense of the "Spa Act“, each spa resort is defined by the territory of the municipality (part of the municipality) or more municipalities where the natural spa is located. The spa treatment combines the effect of natural healing resources with preventive and rehabilitative care and with the treatment of certain chronic diseases. The spa resort and its statute are set by the government regulation.

Subsequently, spa tourism is according to the Explanatory Dictionary of Tourism (Zelenka \& Pásková, 2012, p. 304) „a type of tourism characterized by stays in a spa for the purpose of regeneration, cognition or social contacts. A modern trend is a fitness and preventive medical stay in the spa (wellness program)".

In the same dictionary, the wellness is briefly defined as „recreational, spa and sports activities, aimed at achieving mental and physical health, representing a significant trend of current tourism“ (Zelenka \& Pásková, 2012, p. 631).

The Explanatory Dictionary of Tourism also talks about healing tourism, which is a form of tourism whose „participants are motivated by improving their own health condition, physical and mental condition, well-being, feeling of health, usage of natural resources. These stays are connected with the improvement of the regime, the treatment courses, the procedures and therapies, or the convalescence stays. It does not completely overlap with the spa tourism, as it does not have to be always done in the spa, and the stay in the spa resort does not have to be always connected with healing“ (Zelenka \& Pásková, 2002, p. 306).

\section{Approaches to the research issue}

The aim of this paper is to compare and assess the position of the spa and wellness sector in the structure of tourism in the Czech Republic. The essential means of assessment is spatial analysis, which means "the quantitative study of phenomena that are located in space” (Bailey \& Gatrell, 1995, p. 7). The spatial analysis has a long tradition in the geography of tourism. This includes research on the intensity and structure of visitors, the formation and orientation of tourist and visitor streams, typing and regionalization of tourism tourist sites and regional research of smaller territorial units, regional analyses of larger areas of tourism, regionalization of the national level (Šauer et al., 2015). 
These spatial relationships and contexts represent synthetically a spatial organization of tourism that includes the influence of partial recreational potentials in the form of natural and socio-economic conditions of the territory. The basic tools for studying spatial relationships are descriptive statistical analyses of attendance, multi-criteria evaluation of the importance of tourism centres and cartographic methods.

In this context, the first focal point of the paper is the definition of the spa centres and assessment of their attendance, as well as the evaluation of their significance in the functional and spatial organisation of tourism in the Czech Republic. Finally, the paper addresses the accompanying problem of wellness and wellness tourism. All of this is complemented by cartographic outputs.

There are more approaches to measuring the significance of spa resorts. In addition to purely balneological criteria (e.g., efficacy of healing resources), the attendance is often reported. The economic characteristics (such as the turnover or profits from the sale of the provided services) are also occasionally mentioned. However, it is challenging to access and compare these economic data. Our public statistics provide three different kinds of information for comparative analysis of the spa attendance.

The first is data on balneological care. The source of information is formed on balneological patient care returned by balneal establishments. The data are related to adults, juveniles and children. They are separated for natives and foreigners and classified by the type of financing. The publication contains the numbers of admitted patients and days of treatment according to the above mentioned groups and diagnosis groups.

This information is provided by the Institute of Health Information and Statistics of the Czech Republic in the annual publication of Spa Care in the Czech Republic. The publication provides aggregated data from spa health care facilities in territorial details throughout the Czech Republic and the Czech regions.

The assessment of the importance of spas for tourism development is based on the following available classification criteria:

- number of beds in collective accommodation establishments (2015),

- number of guests in CAE (2015),

- total number of overnight stays in CAE (2015),

- the proportion of overnight stays of foreign guests in \%,

- the proportion of higher category of hotel equipment.

These criteria are designed to make good use of available resources (see above) about the performance and quality of the Czech spa.

The last but not insignificant part of the assessment is a description of the current situation in the field of wellness tourism. Wellness is still a relatively less researched area in the Czech Republic. There is a lack of statistics that would follow the wellness branch separately, as is the case of spa treatment. These statistics would help to find out what facilities provide wellness services, characteristics of customers using the wellness centres and the economic benefits of this sector for the Czech economy as a whole. For the statistical reasons, it is necessary to define what can be included into the wellness services. 
At present, the Czech Wellness Association prepares the certification of wellness facilities in the Czech Republic. In connection with this certification, it is necessary to solve the diversity of accommodation facilities built on wellness philosophy and those that only provide partial wellness services but use the word "wellness" as an effective marketing tool. There is also a lack of studies mapping the needs and wishes of wellness centres customers in marketing studies (Poděbradský, 2008, p. 120).

This is the reason why a partial analysis of wellness tourism in the Czech Republic is presented, which is based on available aquapark information. But the analysis can not be considered as a comprehensive assessment of the wellness infrastructure in the Czech Republic. There is understanding that the presented analysis is only the first insight into the subject matter.

\section{Results}

\section{Spa resorts and statistics of their attendance}

The basic overview of the published data can be characterized as follows:

In 2010, there were 86 spa health facilities in the Czech Republic in a total of 36 spa resorts, which had 26,432 beds in spa facilities. A total of 376,000 domestic and foreign patients were treated in the spas. According to the most recent data for 2015 (for 81 out of a total of 87 registered health spa rehabilitation care providers), over 347,000 spa patients visited the spa for the purpose of the spa rehabilitation treatment (out of which 126 foreign patients, i.e., $36 \%$ with an average length of stay 12.5 days). The total number of treatment days for spa patients was almost 5 million. Therefore, the average length of stay was 14.1 days in 2016. There were almost 23,000 beds in spa facilities.

The second source of information on the spa accommodation facilities is the publication of the Czech Statistical Office in the thematic tourism series, where the attendance in the spa accommodation facilities is monitored. The attendance in the spa accommodation facilities means the number of guests and their overnight stays in the spa facilities irrespective of the method of reimbursement, or the complexity of treatment. The data for 2015 speak about 732 thousand guests (out of which 318 thousand were foreign guests) who accounted for 6.65 million overnight stays (out of which 2.55 million were carried out by foreign guests).

The first set of information thus provides the information on pure spa care, and the second set of information refers to the total number of stays of all spa guests made in the spa accommodation facilities. The comparison of both data (altogether 732 thousand guests and 347 thousand spa patients) shows the significance of 385 thousand spa guests without classical medical care. It means the share over $53 \%$. This number mainly represents an interesting offer of therapeutic accommodation facilities (treatment houses, spa wellness hotels) in the form of dozens of wellness programs (e.g., stays for health, stays for seniors, beauty stays, or extended weekends).

Finally, the third database of information on the spa attendance is provided by the public database of the Czech Statistical Office (CZSO). In the territorial details of the 
Czech Republic, regions, districts and especially individual municipalities provide annual data on the number of beds in the collective accommodation establishments (CAE), the number of domestic and foreign guests and the number of overnight stays of domestic and foreign guests. This is a classic record of the capacities and outputs of the collective accommodation facilities in tourism. These data include both current tourism statistics and spa treatment data from the spa facilities. The aggregate data for 36 spa resorts speak about nearly 52,000 beds in collective accommodation establishments (including 23,000 beds in medical accommodation facilities), housing more than 1.3 million guests with more than 8.1 million overnight stays ( $40 \%$ of foreign guests), i.e., an average of 6.2 overnight stays (Czech Statistical Office, 2017).

The brief assessment of both views on visits of spa resorts shows the importance of purely classical spa care, as well as the forms of spa tourism and wellness stays in the spa. On the one hand, about 350 thousand spa patients and almost 1 million other spa guests in total, respectively, almost 5 million overnight stays in spa patients (with an average stay of 14.4 days) and over 3 million overnight stays for other spa guests (with an average stay of 4.2 days).

\section{Spatial layout of the spas}

The spas are very heterogeneously distributed in the Czech territory. This is mainly related to the location of healing springs and sources. Most of the spas (seven in total) can be found in the territory of the Olomouc Region, the second place with five resorts is the Karlovy Vary Region, the third place with four spas in the Ústí nad Labem Region. Three spa resorts are located in the South Bohemian, Hradec Králové, Moravian-Silesian and Zlín regions, two in the South Moravian, Liberec and Central Bohemia regions, only one spa can be found in the Pardubice and Pilsen regions. No spa is found in Prague and the Vysočina Region. A total of 87 spa facilities in 36 spa resorts were in operation in 2015. More than a half of all spa facilities are located in the Karlovy Vary Region, with 36 facilities in Karlovy Vary (more than 40\%). The spatial layout of our current 36 spas is represented by Figure 1.

To assess the importance of the spas, it is not only their spatial distribution but also the assessment of their bed capacity, the number of guests and overnight stays, In addition, the geographical structure of their visitors and the length of their stay are also important. A basic overview of these characteristics is provided in the following Table and Figure 2. 


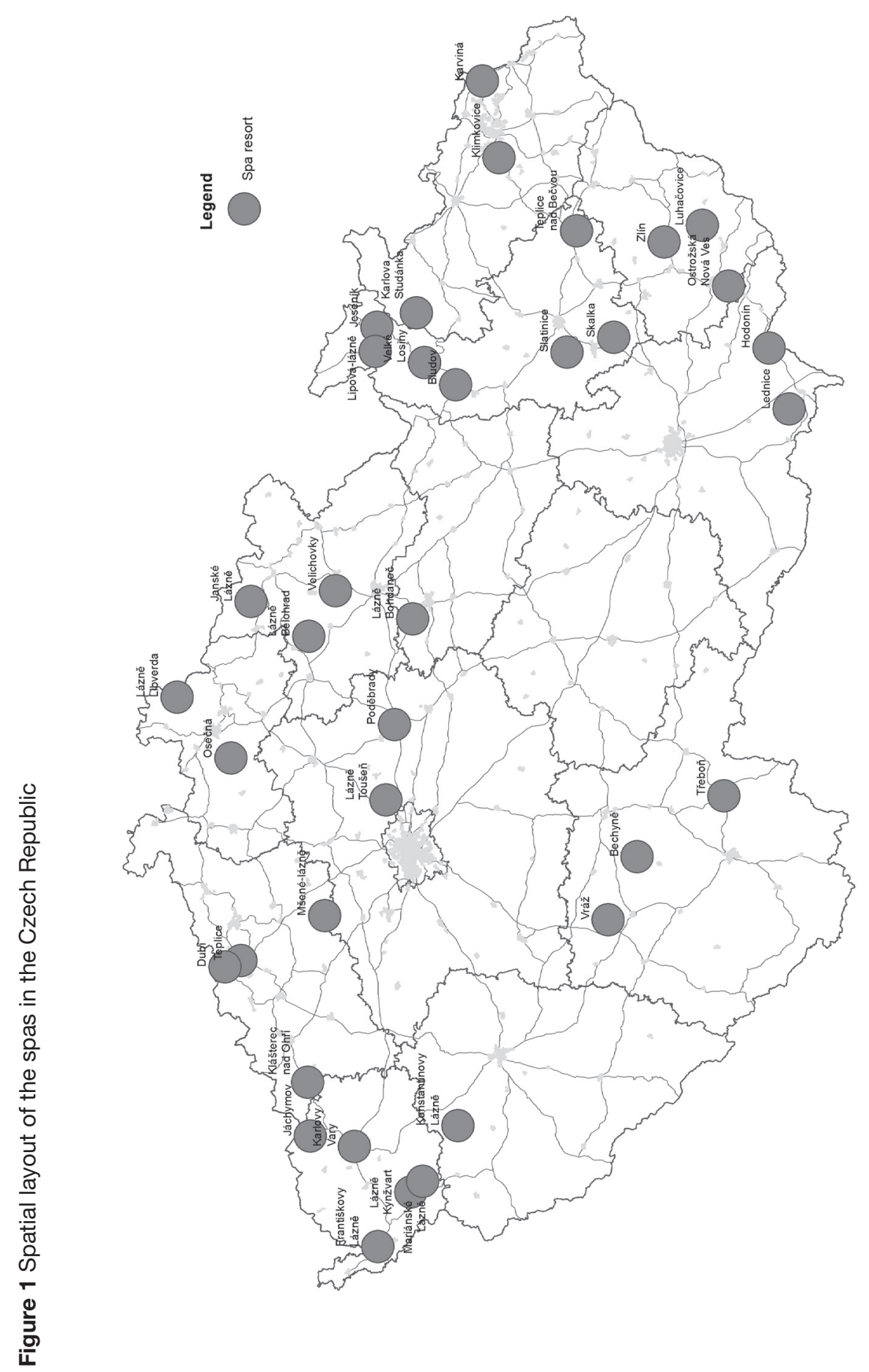

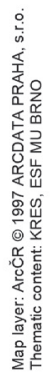

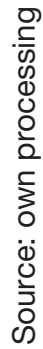


Table 2 Spa resorts in the Czech Republic - bed capacity and attendance 2015

\begin{tabular}{|c|c|c|c|c|c|c|}
\hline spa resort & 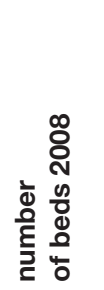 & 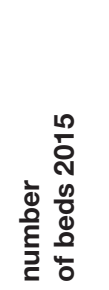 & 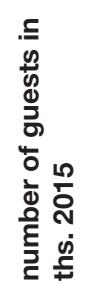 & 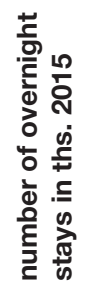 & 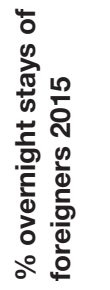 & 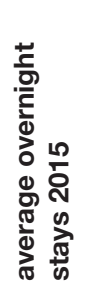 \\
\hline Karlovy Vary & 9,588 & 11,130 & 267 & 1,540 & 81 & 5.8 \\
\hline Mariánské Lázně & 6,188 & 6,642 & 233 & 1,243 & 76 & 5.3 \\
\hline Františkovy Lázně & 4,343 & 4,268 & 106 & 868 & 57 & 8.2 \\
\hline Luhačovice & 3,831 & 3,034 & 107 & 613 & 10 & 5.7 \\
\hline Janské Lázně & 2,243 & 2,925 & 55 & 357 & 16 & 6.5 \\
\hline Třeboň & 1,446 & 2,605 & 63 & 366 & 4 & 5.8 \\
\hline Jáchymov & 1,670 & 2,162 & 36 & 354 & 40 & 9.8 \\
\hline Teplice & 1,776 & 2,075 & 44 & 255 & 42 & 5.8 \\
\hline Poděbrady & 1,707 & 1,930 & 57 & 282 & 17 & 5.0 \\
\hline Jeseník & 1,444 & 1,372 & 43 & 326 & 3 & 7.6 \\
\hline Lednice & 523 & 1,315 & 53 & 113 & 18 & 2.1 \\
\hline Karviná - Darkov & 1,236 & 1,108 & 15 & 238 & 12 & 15.4 \\
\hline Lipová - lázně & 854 & 1,030 & 21 & 64 & 6 & 3.1 \\
\hline Hodonín & 835 & 1,009 & 42 & 152 & 22 & 3.6 \\
\hline Bechyně & 858 & 885 & 14 & 118 & 2 & 8.7 \\
\hline Karlova Studánka & 771 & 746 & 19 & 108 & 2 & 5.8 \\
\hline Lázně Bohdaneč & 478 & 734 & 14 & 149 & 1 & 10.6 \\
\hline Konstantinovy Lázně & 505 & 660 & 11 & 85 & 12 & 10.1 \\
\hline Lázně Bělohrad & 474 & 651 & 15 & 113 & 6 & 7.4 \\
\hline Lázně Libverda & 570 & 612 & 11 & 69 & 10 & 6.5 \\
\hline Teplice nad Bečvou & 358 & 556 & 12 & 120 & 2 & 7.5 \\
\hline Velké Losiny & 631 & 523 & 19 & 107 & 4 & 5.6 \\
\hline Klimkovice & 523 & 491 & 10 & 100 & 4 & 10.0 \\
\hline Lázně Kynžvart & 366 & 453 & 6 & 80 & 3 & 14.5 \\
\hline Ostrožská Nová Ves & 256 & 403 & 9 & 66 & 3 & 7.2 \\
\hline Slatinice & 164 & 399 & 4 & 50 & 1 & 12.5 \\
\hline Vráž & 161 & 333 & - & - & - & - \\
\hline Mšené - lázně & 219 & 325 & 3 & 26 & 1 & 8.6 \\
\hline Velichovky & 453 & 301 & 3 & 34 & 1 & 10.5 \\
\hline Dubí & 219 & 244 & 5 & 25 & 84 & 4.8 \\
\hline Lázně Kundratice & 190 & 242 & 4 & 46 & 11 & 11.9 \\
\hline
\end{tabular}




\begin{tabular}{|c|c|c|c|c|c|c|}
\hline spa resort & 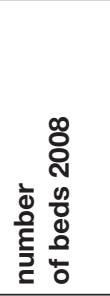 & 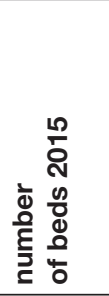 & 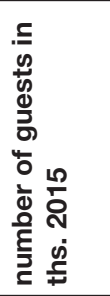 & 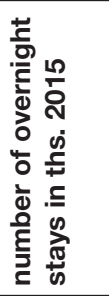 & 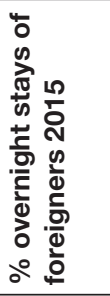 & 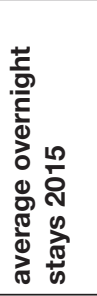 \\
\hline Kostelec u Zlína (Zlín) & 180 & 200 & - & - & - & - \\
\hline Skalka & 21 & 182 & - & - & - & - \\
\hline Klášterec nad Ohři & 254 & 176 & 5 & 13 & 16.1 & 2.7 \\
\hline Bludov & 256 & 161 & 3 & 24 & 2 & 10.3 \\
\hline Lázně Toušeň & 80 & 78 & - & - & - & - \\
\hline Czech Republic & 45,671 & 51,960 & 1,309 & 8,104 & 40 & 6.2 \\
\hline
\end{tabular}

The spas in italics are out of service, respectively without the assigned status Source: Kajlík (2007), Czech Statistical Office (2017), own calculations and estimates

The number of beds in Table 2 gives the sum of the beds in the spa facilities and in the hotels, guest houses and other collective accommodation establishments in the given spa resort (municipality). The total number of almost 52 thousand beds in 2015 represents about one tenth of the total bed capacity in the collective accommodation establishments in the Czech Republic, out of which almost 23 thousands (44\%) were the number of beds in the spa accommodation facilities. Most of the 52 thousands beds in the above-mentioned spas are mainly in the higher category of the hotel type $(* * * *$ and ***** hotels, spa houses).

From the point of view of the attractiveness of the spas for the overall spa tourism, the average length of stay of the spa guest is an interesting indicator. The lower values of this indicator (despite a significant number of spa patients) signal the overall attractiveness of the spa, where the overall attractiveness of the spa environment, or even the functions of urban and mountain tourism, is often attributed to the balneological function. Such examples may be Karlovy Vary, Mariánské Lázně, Luhačovice, Třeboň, Janské Lázně, Poděbrady, Teplice, Karlova Studánka and Lednice (this is clearly connected with the dominant attraction of the UNESCO site, not the spa function). At the opposite pole of attractiveness, there are mostly small spa resorts, specializing mainly in the spa treatment, without significant social life attractions and corresponding infrastructure of spa tourism. This example includes Teplice nad Bečvou, Lázně Bohdaneč, Konstantinovy Lázně, Klimkovice, Velichovky, Kundratice, Bludov, Vráž, Slatinice and Karviná - Darkov. 


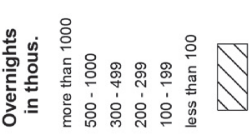

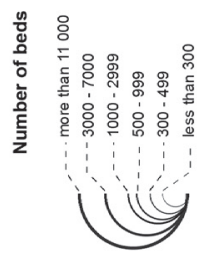

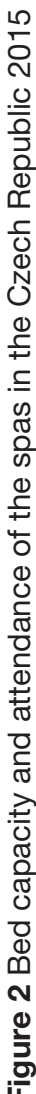

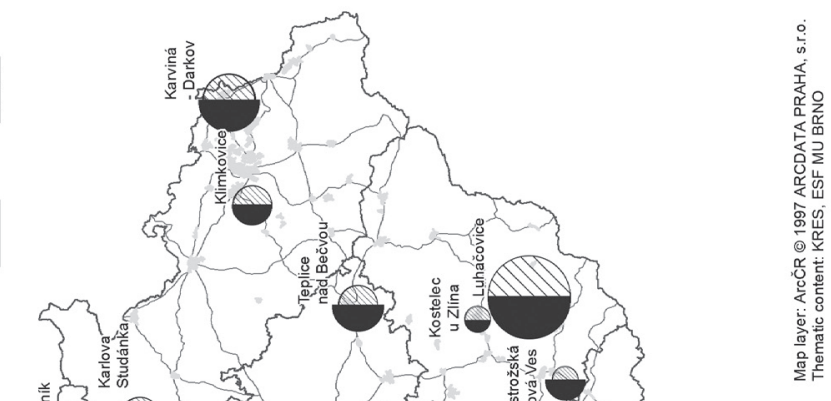

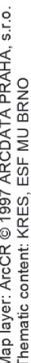

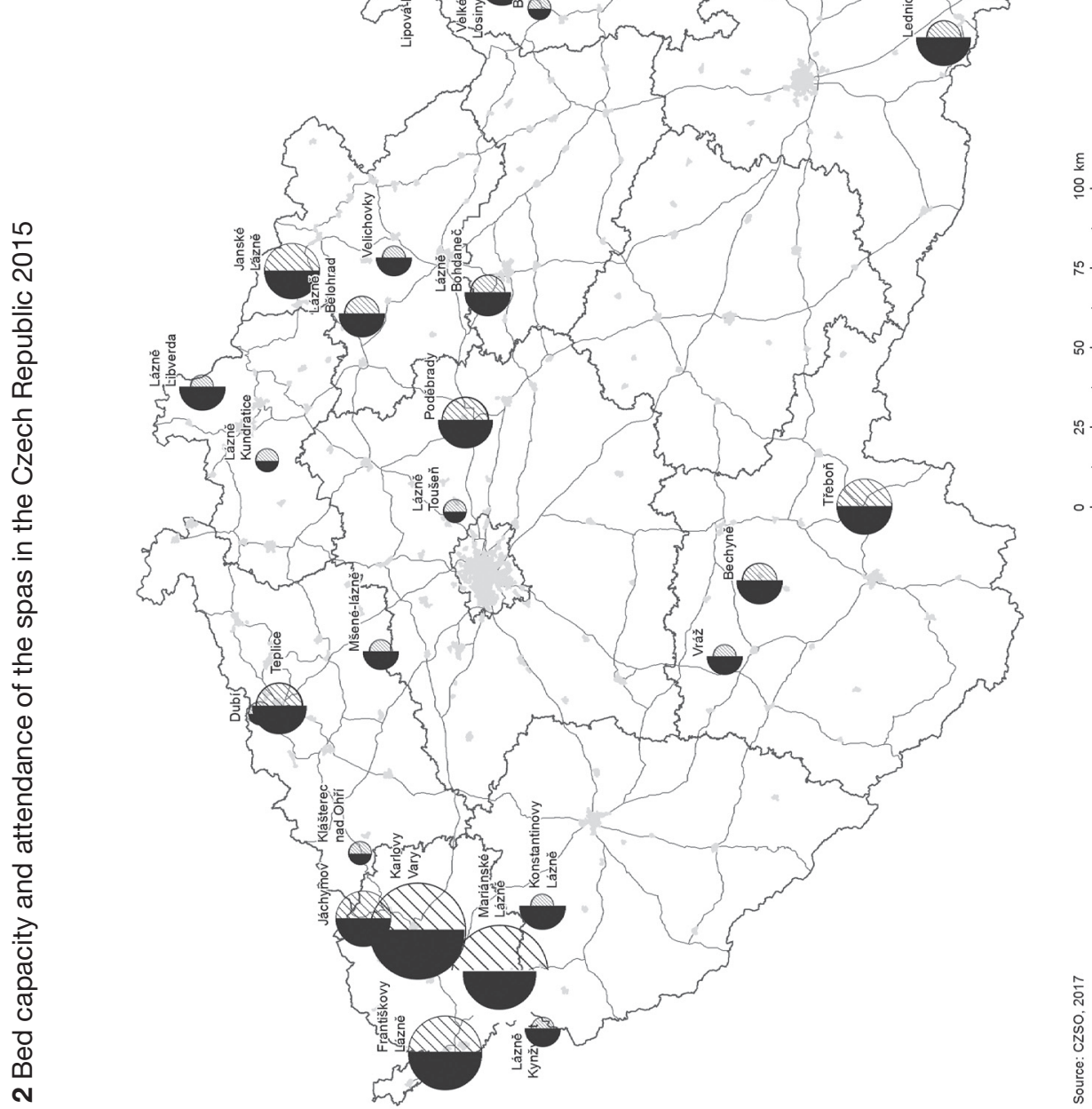

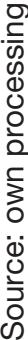




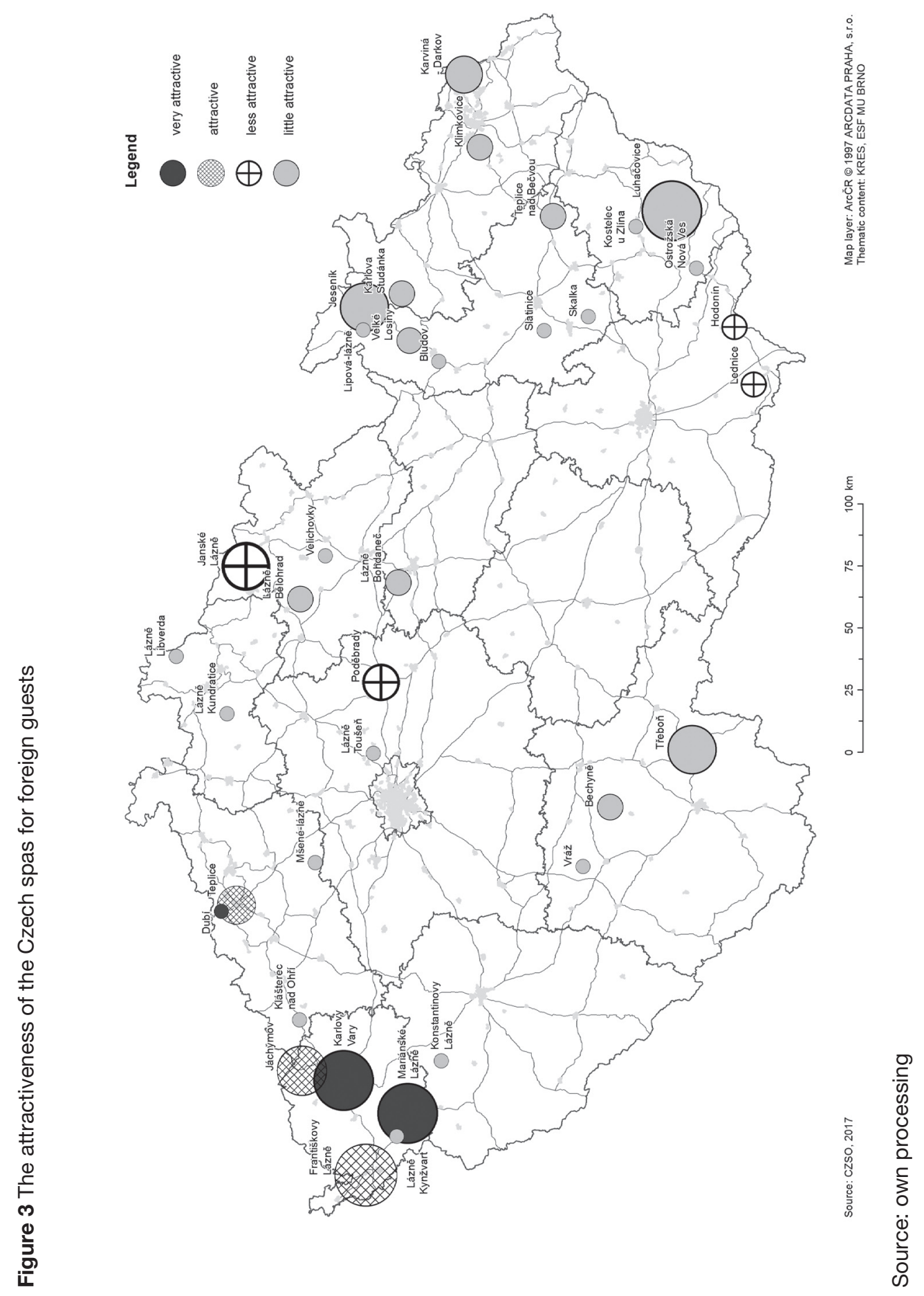




\section{Assessment of the importance of the spas for spa tourism}

Spa and especially spa tourism are an important part of tourism in the Czech Republic. For example, in 2015, the bed capacity in CAE in the spas accounted for almost $10 \%$ of the total bed capacity of CAE in the Czech Republic, almost $8 \%$ of the number of guests and $17 \%$ of the number of overnight stays in CAE in the Czech Republic. The number of foreign guests is also important; the proportion of their overnight stays in our spas was $40 \%$ in 2015.

From the previous tabular and cartographic reports, there is a clear difference in the size of our spa resorts regarding their total attendance, above all in terms of their attractiveness for spa tourism. According to the above mentioned characteristics, the following evaluation of the attractiveness of their importance for spa tourism was compiled (see also Kunc, 2011, p. 127).

Table 3 Evaluation of the attractiveness of the resorts for spa tourism

\begin{tabular}{|l|l|}
\hline Importance & Spa resort \\
\hline Global & Karlovy Vary, Mariánské Lázně, \\
\hline International & Františkovy Lázně, Teplice, Jáchymov, Luhačovice, Poděbrady \\
\hline National & Jeseník, Třeboň, Janské Lázně, Bechyně \\
\hline Regional & $\begin{array}{l}\text { Hodonín, Lázně Bohdaneč, Velichovky, Velké Losiny, Teplice nad } \\
\text { Bečvou, Lázně Bělohrad, Konstantinovy Lázně, Lázně Kynžvart, } \\
\text { Karlova Studánka, Lázně Libverda, Lednice, Karviná-Darkov, Lipová } \\
\text { Lázně }\end{array}$ \\
\hline Local & $\begin{array}{l}\text { Dubí, Mšené-Lázně, Vráž, Kostelec (Zlín), Bludov, Klášterec nad } \\
\text { Ohří, Slatinice, Ostrožská Nová Ves, Lázně Kundratice (Osečná), } \\
\text { Lázně Toušeň, Skalka, Klimkovice, }\end{array}$ \\
\hline
\end{tabular}

Source: based on Kunc (2011, p. 127-128)

According to this evaluation, the spas are divided into five groups based on their importance for spa tourism. Karlovy Vary and Mariánské Lázně are allocated to a separate category of global importance, since their importance significantly exceeds all other spas, both in the number of beds and in the total number of visitors, the share of payers, the quality and the quantity of services provided, as well as in accompanying sports and relaxation activities and other indicators (Kunc, 2011, p. 128). In the category of international importance, there are other spas (Františkovy Lázně, Luhačovice, Poděbrady, Teplice and Jáchymov) with a total of more than 2,000 beds in CAE and more than 250 thousands overnight stays of spa guests, with a significant proportion of foreign visitors (at least 10\%). The remaining spas were included in one of the other categories of national, regional and local significance. 


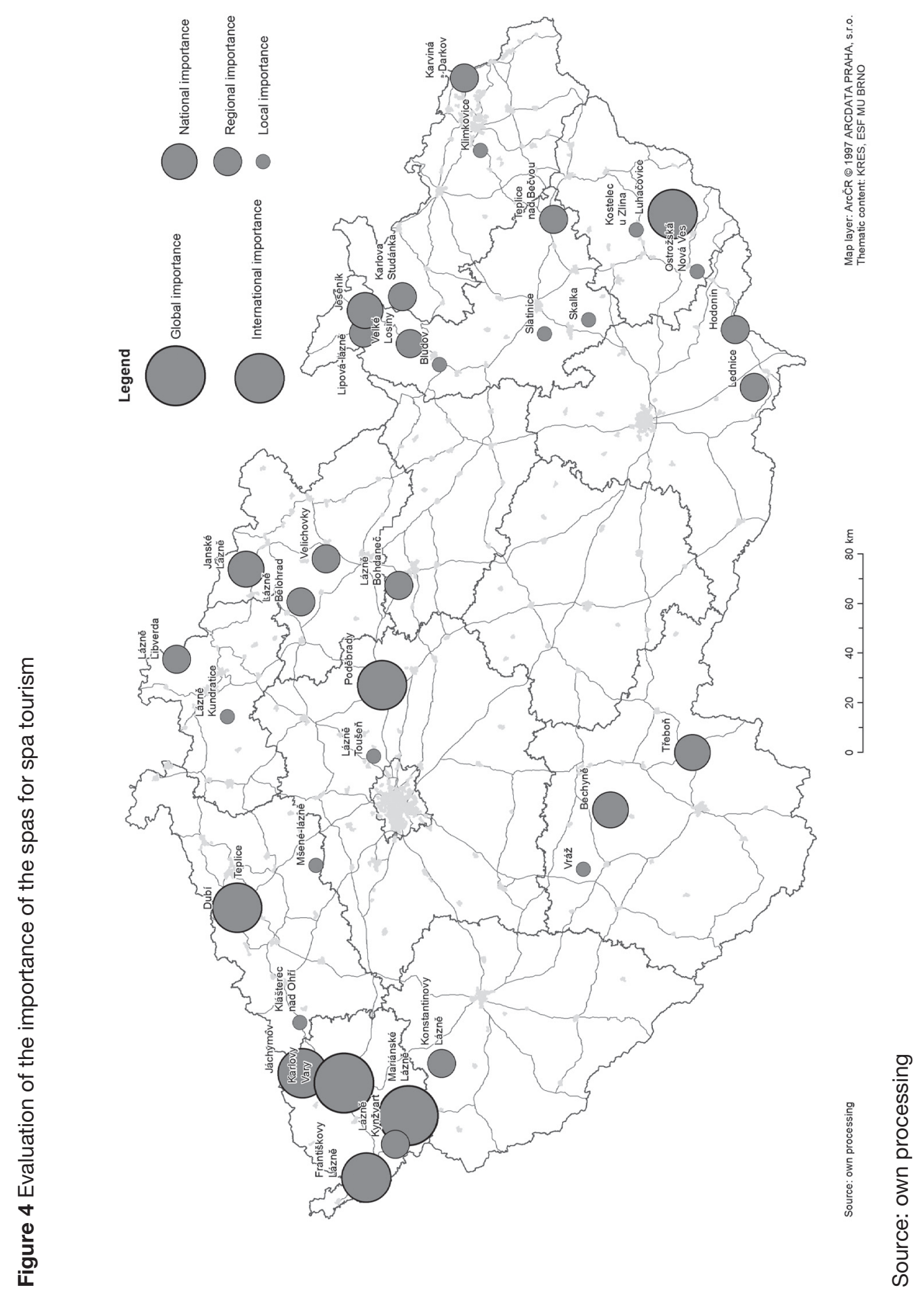




\section{Wellness and wellness tourism}

In the Czech Republic, wellness is usually considered to be a difficulty definable area of activity between spa and fitness. The concept of wellness is undoubtedly a phenomenon of today's time; and wellness services are an important part of hotels, spa and relaxation facilities. Wellness can be understood as a synonym of a healthy lifestyle (Poděbradský, 2008, p. 7). In the Explanatory Dictionary of Tourism (Zelenka \& Pásková, 2012, p. 631), wellness is briefly defined as "recreational, spa and sports activities aimed at achieving mental and physical health, a significant trend in current tourism”. According to another definition (Attl, 2006a), wellness is considered to be the activity of people leading to the feeling of satisfaction from the well-being created by a set of pleasant impulses. These include movement, regeneration, pleasant music, relaxation, tasty food and drinks, positive feelings and enjoyment.

From a modern perspective point of view, wellness is a combination of relaxation and treatment methods. On the other hand, the spa treatment includes, in addition to the healing functions, some aspects of wellness products. This fact raises the question of the difference between the spa and wellness. The most important difference, according to Poděbradský (2008), is that the spa has a healing function and its aim is to heal or treat health complications. The goal of wellness is, on the other hand, to prevent these problems by a healthy lifestyle. Attl (2006a) adds that the spa is basically (except for Jeseník Spa) tied to natural healing springs, and wellness facilities can work both in the spa and outside the spa without any need to be bound to natural healing springs (Kunc, 2011, p. 129).

In the Czech Republic, the idea of wellness got into the strategies of accommodation facilities, spa centres and fitness centres in the 1990s. The popularity of wellness is gradually increasing; it represents a very promising field of business activity and undergoes dynamic development. Support funds OF European Union had a major contribution to the development of wellness and wellness tourism in the Czech Republic in the period 2004-2015 (programme ERDF - European Regional Development Fund). In 2007, the Czech Wellness Association (CWA) was established. Unlike other Central European countries, however, the Czech Republic has not ranked the top positions in the provision of these services (Kunc, 2011, p. 129). Currently, Hungary and Slovakia (also with significant support from the ERDF) take the lead position; in Western Europe dominate Switzerland, Germany and Austria.

Spa in the Czech Republic is anchored in the system of providing medical care. The spa treatment also means a fixed schedule of procedures and specific spa regimes, which are nowadays more and more liberal. Spa treatment also differs in the way of financing. Whilst the participants of the wellness stays are exclusively self-payers, the spa stays can be completed in the framework of comprehensive or contributory spa care - the stay can be entirely or partly paid by the health insurance company, but there is also the possibility of self-payment. The existence of a spa facility is also tied to the presence of a natural healing spring, while the wellness facility can work without its presence. Other differences are found in the average length of stays, while the traditional spa stays last 


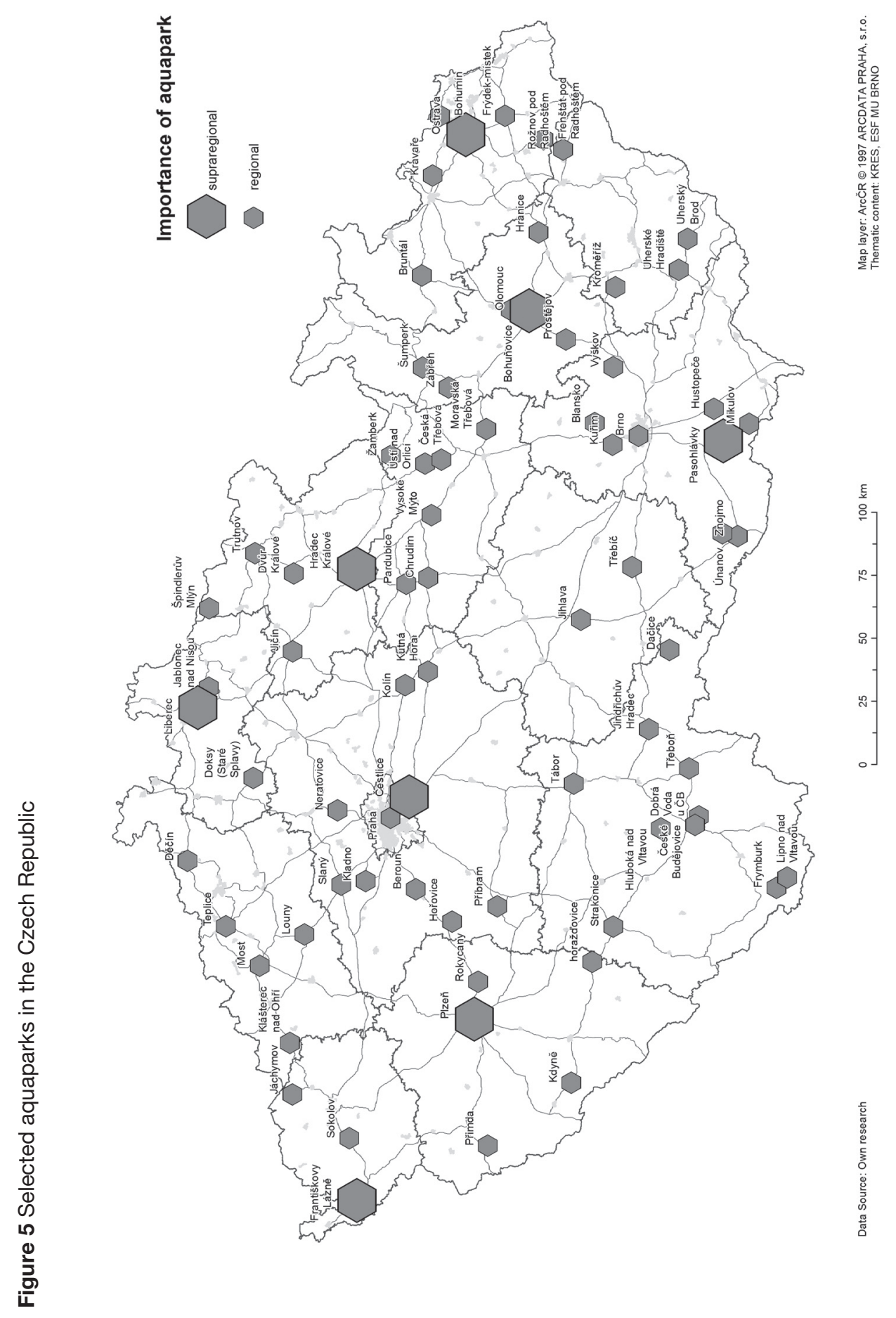

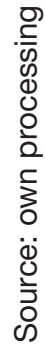


14, 21 or 28 days, the relaxation stays are on average shorter; weekend or week wellness stays are very frequent (Poděbradský, 2008, p. 8). Wellness tourism is one of the shortterm forms of tourism - the average length of wellness stays is around 2.5 days. This is also the reason for the marketing and implementation of wellness programs.

If the main forms of wellness activities are evaluated from the point of view of the highest added value for tourism in the Czech Republic, short-term relaxation hotel and spa stays with wellness programs and activities and mostly one-day visits in aquaparks undoubtedly are part of this category. Currently, there are more than 700 hotels in the Czech Republic (including guest houses), with the label wellness. It can give an impression of a very high number, however, when examining the scope of supply and quality, this number is considerably lower. Compared to the European standard, only about one tenth of them would be acceptable. In terms of geographic location, our major spa centres (Karlovy Vary and Mariánské Lázně) dominate; then Prague, large (regional) towns, and notably important mountain resorts (e.g., Špindlerův Mlýn), rarely resorts of summer recreation.

A similar history of turbulent development was observed in the Czech Republic in the construction of modern aquaparks and aquacentres, especially after the year of 2000 . Their construction was often supported by the EU funds under the Regional Operational Programs (ERDF). Support of their construction from these funds was carried out, for example, in Karlovy Vary, Pasohlávky, Jindřichův Hradec, Kuřim, Sokolov, Bruntál, Horaždovice, and in many other towns. The visits in aquaparks and centres present a specific form of short-term (predominantly, one-day) tourism. Compared to other European countries with more favourable natural conditions for this form (especially the existence of thermal springs in Hungary, Austria and Slovakia), our sites lack the appropriate infrastructure for residential tourism. In most cases, projects of local importance are concentrated primarily in towns as a part of their basic or complementary amenities. There are currently about 70-80 such localities in our area. Only a few aquaparks meet the criterion of the least regional importance, e.g., the oldest aquapark in the Czech Republic - Babylon in Liberec, the largest aquapark in the Czech Republic - Aquapalace Prague on the outskirts of Prague (the village Čestlice) or the youngest modern aquapark in the Czech Republic - Aqualand Moravia in Pasohlávky in South Moravia.

\section{Conclusion}

The history, tradition and quality of natural healing resources and, in recent years, services, have been the preconditions for the Czech Republic and the further development of spa care, spa and wellness tourism. For the future successful development of this important tourism sector, it is necessary to adapt the offer to the new trends and demands of the quality programs and products of spa tourism in our spa resorts and the products and activities of relaxation wellness stays in other attractive destinations of the Czech Republic. In the professional literature the opinion prevails (e.g., Kunc, 2011; Attl, 2006a, 2006b; Poděbradský, 2008), that Slovakia, Hungary and Slovenia dealt with the changes 
in demand in Central Europe successfully. The Czech Republic started later; however, there are particularly positive trends after the year 2000, especially in the more important spa and mountain resorts and in Prague. The EU support funds in the form of regional operational programs for the period of 2007-2013 meant the significant impetus for building wellness centres, aquaparks and modern spa infrastructure. For example, in the last 10 years, the number of beds in the collective accommodation establishments increased by $36 \%$ in 36 spas in the Czech Republic.

Despite the current lower competitiveness, the development of the Czech wellness tourism in both quantitative and qualitative directions is likely to be expected in the future. A number of wellness hotels and facilities in spa care will grow, and the quality of services will increase. An important step will adapt to the conditions and requirements of older people for wellness services, which will undoubtedly be the customer base of this modern business discipline due to the demographic trends (Kunc, 2011, p. 130).

\section{Acknowledgment}

The financial support of the Specific Research Project MUNI/A/1046/2016 "The primary research into small and medium-sized enterprises in tourism" of Masaryk University is gratefully acknowledged.

\section{References}

Attl, P. (2006a). Fenomén jménem wellness (Phenomenon Wellness). Vademecum zdravi, 2(Summer), 64-66. Retrieved from http://vademecum-zdravi.cz/fenomen-jmenem-wellness/ .

Attl, P. (2006b). Nové lázně v Česku (New Spa in the Czech Republic). Vademecum zdraví, 2(Autumn), 70-72. Retrieved from http://vademecum-zdravi.cz/nove-lazne-v-cesku/.

Bailey, T. C., \& Gatrell, A. C. (1995). Interactive Spatial Data Analyis. In C. M. Hall (2012), Spatial Analysis: A critical tool for tourism geographies. In J. Wilson (Ed.), The Routledge Handbook of Tourism Geographies (pp. 163-173). London/New York: Routledge.

Benda, J. (1979). Ochrana a péče o životni prostředi přírodnich léčebných lázni: bioklimatologické, medicinskoekologické, balneohygienické a práuni aspekty (Protection and care of the environment of natural healing spas: bioclimatological, medical-ecological, balneo-hygienic and legal aspects). Mariánské Lázně, Czech Republic: Research Institute of Balneology.

Benešová, P., \& Kruisová, H. (2013). Řizeni subjekti̊ zdravotně orientovaného cestovního ruchu (Management of Health-oriented Tourism Subjects). Prague, Czech Republic: Idea Servis.

Benešová, P., \& Kruisová. H. (2015). Zdravotně orientovaný cestovni ruch (Health-oriented Tourism). Prague, Czech Republic: Idea Servis.

Burachovič, S., \& Wieser, S. (2001). Encyklopedie lázni a léčivých pramenů v Čechách, na Moravě a ve Slezsku (Encyclopedia of spas and healing springs in Bohemia, Moravia and Silesia). Prague, Czech Republic: Libri.

Černý, B. V. (1945). Základy poznání cestovního ruchu (Basic Knowledge of Tourism). Prague, Czech Republic: ÚSCR. 
Černý, B. V. (1969). Základy ekonomiky lázeňstvi (Basics of Spa Economy). Prague, Czech Republic: Balnea.

Czech Statistical Office. (2017). Počet hostů a přenocování v lázeňských ubytovacích zařízeních v ČR 2013-2015 (Number of Guests and Overnights in Spa Accommodation Establishments in the Czech Republic 2013-2015). Public Database [statistics]. Retrieved from https://vdb2.czso.cz/

Fialová, D. (2004). České lázeňství (Czech Balneology). Geografické rozhledy, 13(3), 76-77.

Houdek, J. (2003). Almanach lázeňských mist v České republice (Almanac of spa resorts in the Czech Republic). Czech Republic: Sdružení lázeňských míst ČR.

Charvát, J. (1948). Cestovni ruch v konjunkturním výzkumu (Tourism in conjunctural research). Prague, Czech Republic: Orbis.

Chovanec, J. (1966). Československé přirodni léčebné lázně a přirodni léćivé zdroje - právni zabezpečeni jejich rozvoje a ochrany (Czechoslovak natural healing spa and natural healing resources - legal protection of their development and protection). Prague, Czech Republic: Ministry of Health, ÚSLZ.

Jakubíková, D., \& Vildová, E. (2014). Spokojenost lázeňského hosta (Satisfaction of the Spa Guest). In 3. mezinárodni vědecká conference Cestovni ruch, hotelnictvi a lázeňstvi ve světle vědeckéh výzkumu a praxe, Karviná, 14.-15. květn 2014. Sbornik recenzovaných přispěvků. (3rd International Scientific Conference Tourism, Hospitality and Spa in the Light of Scientific Research and Practice, Karviná, May 14 - May 15, 2014. Proceedings of reviewed papers) (pp. 152-163). Karviná, Czech Republic: The Silesian University in Opava.

Kajlík, V. (2007). České lázně a lázeňstvi (Czech Spa Resorts and Balneology). Prague, Czech Republic: Ministry for Regional Development of the Czech Republic.

Kostková, M., Němčanský, M., \& Torčíková, E. (2009). Management služeb cestovního ruchu (Tourism Services Management). Karviná, Czech Republic: Silesian University in Opava.

Kubová, O. (2012). Wellness v cestovním ruchu (Wellness in Tourism). Brno, Czech Republic: Karel Englis College.

Kunc, J. (2007). Lázeňský cestovní ruch v České republice - historie a současnost (Spa Tourism in the Czech Republic - Past and Present). In Czech Geography in the European Space: Sbornik př́spěvkĩ z XXI. sjezdu České geografické společnosti. České Budějovice, 30. 8. - 2. 9. 2006 (pp. 147152). České Budějovice, Czech Republic: University of South Bohemia in České Budějovice.

Kunc, J. (2011). Lázeňství, lázeňský cestovní ruch a wellness (Spa, Spa Tourism and wellness). In J. Vystoupil, M. Šauer et al., Geografie cestovního ruchu České republiky (pp. 122-130). Plzeň, Czech Republic: Vydavatelství Aleš Čeněk.

Migala, M., \& Szczyrba, Z. (2006). Spas and spa tourism in the Czech Republic. Zeszyty Naukowe: seria Turystyka i Rekreacja, Nr. 312/2006, z. 1, 147-162. Opole, Poland: Politechnika Opolska.

Institute of Health Information and Statistics of the Czech Republic. (2009). Lázeñská péce 2008 (Spa care 2008). Prague, Czech Republic: ÚZIS ČR. Retrieved from http://www.uzis.cz/system/files/lazne2008.pdf.

Institute of Health Information and Statistics of the Czech Republic. (2010). Lázeñská péče 2009 (Spa care 2009). Prague, Czech Republic: ÚZIS ČR. Retrieved from http://www.uzis.cz/system/files/lazne2009.pdf.

Institute of Health Information and Statistics of the Czech Republic. (2011). Lázeňská péce 2010 (Spa care 2010). Prague, Czech Republic: ÚZIS ČR. Retrieved from http:/ /www.uzis.cz/system/ files/lazne2010.pdf.

Institute of Health Information and Statistics of the Czech Republic. (2012). Lázeñská péce 2011 (Spa care 2011). Prague, Czech Republic: ÚZIS ČR. Retrieved from http:/ /www.uzis.cz/system/ files/lazne2011.pdf. 
Institute of Health Information and Statistics of the Czech Republic. (2013). Lázeñská péce 2012 (Spa care 2012). Prague, Czech Republic: ÚZIS ČR. Retrieved from http:/ /www.uzis.cz/system/ files/lazne2012.pdf.

Institute of Health Information and Statistics of the Czech Republic. (2014). Lázeňská péč 2013 (Spa care 2013). Prague, Czech Republic: ÚZIS ČR. Retrieved from http:/ /www.uzis.cz/system/ files/lazne2013.pdf.

Institute of Health Information and Statistics of the Czech Republic. (2015). Lázeňská péče 2014 (Spa care 2014). Prague, Czech Republic: ÚZIS ČR. Retrieved from http:/ /www.uzis.cz/system/ files/lazne2014.pdf.

Institute of Health Information and Statistics of the Czech Republic. (2016). Lázeňská péče 2015 (Spa care 2015). Prague, Czech Republic: ÚZIS ČR. Retrieved from http://www.uzis.cz/system/ files/lazne2015.pdf.

Poděbradský, J. (2008). Wellness v $\check{C} R$ (Wellness in the Czech Republic). Prague, Czech Republic: Ministry for Regional Development of the Czech Republic.

Seifertová, V. (2003). Marketing v lázeňském cestovním ruchu (Marketing in Spa Tourism). Prague, Czech Republic: Pragoline.

Schwartzhoffová, E. (2016). Lázeňstvi a wellness (Spa and Wellness). Olomouc, Czech Republic: Palacký University Olomouc.

Smolová, I. (2004). Spa in the Czech Republic. Velký atlas světa: encyklopedie geografie: world geographic, 2(31), 149-152.

Smolová, I., \& Szczyrba, Z. (2005). Lázeňství v České republice - tradice a nový rozměr (Spa in the Czech Republic - Tradition and New Dimension). Veřejná správa, 16(45), XI-XII.

State Statistical Office. (1928). Statistická př́ručka republiky Československé (Statistical Handbook of the Republic of Czechoslovakia), svazek III. Prague, Czech Republic: Státní úřad statistický (State statistical office).

Sudíková, L. (2009). Lázeňský cestovni ruch v České republice a Evropè (Spa tourism in the Czech Republic and in Europe). Diploma thesis. Brno, Czech Republic: Masarykova univerzita.

Šauer, M., Vystoupil, J., Holešinská, A. et al. (2015). Cestovní ruch. Učebni text. (Tourism: Study text). Brno Czech Republic: Masarykova univerzita.

Špišák, L., Rušavý, Z. et al. (2010). Klinická balneologie (Clinical Balneology). Prague, Czech Republic: Karolinum.

Trachta, S. (1973). Teorie a praxe ochrany lázní před urbanizací z hlediska lázní (Theory and practice of spa protection against urbanization from a spa point of view). In B. V. Černý (Ed.), 2nd Balneological Colloquium (pp. 186-194). Mariánské Lázně, Czech Republic: VÚB.

Vaníček, J., \& Vavrečková, E. (2013a). Profil návštěvníka vybraných lázeňských míst v České republice (Visitor Profile of Selected Spa Resorts in the Czech Republic). In R. Balakovská (Ed.), $5^{\text {th }}$ International Scientific Conference on Hospitality, Tourism and Education. Perspectives 2020. Proceedings (pp. 349 - 366). Prague, Czech Republic: The Institute of Hospitality Management in Prague.

Vaníček, J., \& Vavrečková, E. (2013b). Význam lázeňství pro cestovní ruch vybraných lázeňských míst v České republice (The Importance of Spa Tourism for Selected Spa Resorts in the Czech Republic). In R. Balakovská (Ed.), $5^{\text {th }}$ International Scientific Conference on Hospitality, Tourism and Education. Perspectives 2020. Proceedings (pp. 367 - 381). Prague, Czech Republic: The Institute of Hospitality Management in Prague.

Vavrečková, E. (2015). Komparace přístupů k typologii lázeňských míst v podmínkách České republiky (Comparison of Approaches to Spa Resorts Typology in the Czech Republic). In 
Proceedings from 4th International Scientific Conference Current Trends in Tourism, Hotel and Spa (pp. 311-324). Opava, Czech Republic: The Silesian University in Opava.

Vavrečková, E., \& Vaníček, J. (2014). Přínos lázeňských míst cestovnímu ruchu v Karlovarském a Zlínském kraji (The Contribution of Spa Resorts to Tourism in the Karlovy Vary and Zlín Region). In $4^{\text {th }}$ International Scientific Conference on Hospitality, Tourism and Education. Inovation and Quality of services. Proceedings (pp. 357 - 374). Prague, Czech Republic: The Institute of Hospitality Management in Prague.

Vildová, E., Martinčík, D., Tlučhoř, J., \& Jakubíková, D. (2015). Measuring Customer Satisfaction and Loyalty in Spa Companies. E+M Ekonomie a Management, 18(1), 151-168. DOI: 10.15240/ tul/001/2015-1-012.

Vystoupil, J. (1977). Cestovni ruch a rekreace v lázeňském prostředi Luhačovic (Tourism and Recreation in Spa Environment of Luhačovice). Rigorous thesis. Brno, Czech Republic: University of Jan Evangelist Purkyně.

Vystoupil, J. et al. (2006). Atlas cestovního ruchu České republiky (The Tourism Atlas of the Czech Republic). Prague, Czech Republic: Ministry for Regional Development of the Czech Republic.

Vystoupil, J., Šauer, M. et al. (2011). Geografie cestovního ruchu České republiky (Geography of Tourism in the Czech Republic). Plzeň, Czech Republic: Vydavatelství Aleš Čeněk.

Zelenka, J., \& Pásková, M. (2012). Cestovni ruch. Výkladový slovnik (The Explanatory Dictionary of Tourism). Prague, Czech Republic: Linde. 